6-1988

\title{
Herbivore Grazing Increases Polyphenolic Defenses in the Intertidal Brown Alga Fucus Distichus
}

Kathryn L. Van Alstyne Dr.

Western Washington University, kathy.vanalstyne@wwu.edu

Follow this and additional works at: https://cedar.wwu.edu/shannonpoint_facpubs

Part of the Environmental Sciences Commons, and the Marine Biology Commons

\section{Recommended Citation}

Van Alstyne KL (1988) Herbivore grazing increases polyphenolic defenses in the brown alga Fucus distichus. Ecology 69: 655-663. DOI: $10.2307 / 1941014$

This Article is brought to you for free and open access by the Shannon Point Marine Center at Western CEDAR. It has been accepted for inclusion in Shannon Point Marine Center Faculty Publications by an authorized administrator of Western CEDAR. For more information, please contact westerncedar@wwu.edu. 


\title{
HERBIVORE GRAZING INCREASES POLYPHENOLIC DEFENSES IN THE INTERTIDAL BROWN ALGA FUCUS DISTICHUS
}

\author{
KATHRYN L. VAN Alstyne ${ }^{2}$ \\ Department of Zoology, University of Washington, Seattle, Washington 98195 USA
}

\begin{abstract}
Although predator-induced defenses have been reported for several species of terrestrial vascular plants, they have not been previously described in aquatic or nonvascular plants. In this study, field manipulations were used to demonstrate the presence of inducible chemical defense production in the intertidal brown alga Fucus distichus. When experimentally damaged, Fucus increased its concentrations of polyphenolic compounds by $\approx 20 \%$ over uninjured control plants within $2 \mathrm{wk}$. These increases occurred in the area where the plant was injured and within adjacent undamaged branches. The increase in concentrations of polyphenolic compounds in clipped plants in these experiments corresponded well with differences in phenolic levels in naturally grazed and ungrazed algae.

Herbivorous snails (Littorina sitkana) showed a preference for clipped plants immediately after they were wounded. However, over a 2 -wk period the snails shifted their preference towards the uninjured control plants, corresponding with the increase in polyphenolic levels within the experimentally damaged plants. $L$. sitkana spent less time feeding on clipped plants, and these plants lost $\approx 50 \%$ less tissue (by surface area) to grazers than did uninjured algae. The presence of induced defenses in algae causes plant quality to vary spatially and temporally. This may result in variation in intra- and interspecific food preferences of herbivores, and ultimately may affect benthic algal community structure.
\end{abstract}

Key words: behavior; chemical defenses; Fucus; herbivory; induced defenses; intertidal; Littorina; plant defenses; plant-herbivore interactions; polyphenolic compounds; seaweeds.

\section{INTRODUCTION}

Herbivory is an important factor in determining the structure of benthic algal assemblages in marine communities. Grazing by herbivorous fishes, echinoderms, and molluscs has been shown to play a role in determining the diversity, abundance, and species composition of algae in both intertidal and subtidal communities (see reviews by Lubchenco and Gaines 1981 and Hawkins and Hartnoll 1985). Grazers may also affect plant fitness, not by decreasing survivorship, but by influencing growth rate and reproductive output.

Food preferences of herbivores are important in mediating the effects of herbivores on the distribution and abundance of marine algae (Vadas 1977, Lubchenco 1978). Preferences can be influenced by a number of physical and chemical characteristics of the potential prey (Vadas 1977, Paul and Hay 1986), which, in some cases, are thought to have evolved in response to selection pressures imposed by herbivory. Physical features that may affect herbivore choice include an alga's size and shape (Littler and Littler 1980, Hay 1981, Steneck and Watling 1982), toughness (Watson and Norton 1985a,b), degree of calcification (Paul and Hay 1986), cuticle production (Gaines 1985 ), and produc-

\footnotetext{
${ }^{1}$ Manuscript received 5 February 1987; revised 7 August 1987; accepted 9 August 1987

${ }_{2}^{2}$ Present address: University of Guam Marine Laboratory, U.O.G. Station, Mangilao, Guam 96923.
}

tion of protuberances. An alga's chemical composition may affect herbivore choice because it determines the nutritive value of the plant and because some chemicals deter feeding (Geiselman 1980, Geiselman and McConnell 1981, McConnell et al. 1982, Steinberg 1984, 1985, Paul and Hay 1986, Paul and Van Alstyne 1987).

Marine algae produce a variety of secondary metabolites whose primary function appears to be herbivore deterrence (Norris and Fenical 1982, Faulkner 1984). These compounds are thought to reduce digestibility or plant nutritional qualities, affect nervous system or cardiac functions, or be otherwise toxic or unpalatable to herbivores. No algal secondary metabolites have yet been reported to function as feeding stimulants.

It is assumed that there is a cost in the production of defensive compounds that is reflected in decreases in the growth rate, reproductive output, or competitive ability of the organisms producing them (McKey 1979, Coley et al. 1985, Coley 1986, Harvell 1986). For a particular defense to be favored by natural selection, it should not require a greater investment of a plant's resources than would otherwise be lost to herbivory. A plant producing too many defenses would be at a competitive disadvantage relative to those producing fewer defenses because of its low growth rate or reproductive output. This could be especially critical in communities where space is limiting or where success depends upon spore availability when new patches open 
TABLE 1. Densities of herbivores that were observed to feed on Fucus distichus from the main beach and Pole Island Draw study sites. Data are means \pm 1 SE of $n$ replicate measurements taken with a $10 \times 10 \mathrm{~cm}$ quadrat in May 1986.

\begin{tabular}{lcc}
\hline \hline & \multicolumn{2}{c}{ Herbivore density (no./m²) } \\
\cline { 2 - 3 } Herbivore species & Main Beach & $\begin{array}{c}\text { Pole Island } \\
\text { Draw }\end{array}$ \\
\hline Littorina sitkana & $200 \pm 163$ & $4120 \pm 591$ \\
& $(n=3)$ & $(n=10)$ \\
Littorina scutulata & $167 \pm 33$ & $570 \pm 130$ \\
& $(n=3)$ & $(n=10)$ \\
Siphonaria thersites & $0 \pm 0$ & $40 \pm 22$ \\
& $(n=3)$ & $(n=10)$ \\
Idotea wosnesenskii & $0 \pm 0$ & $0 \pm 0$ \\
& $(n=3)$ & $(n=10)$ \\
\hline
\end{tabular}

up. On the other hand, a plant producing too few defenses would suffer high tissue losses or death because it would be a more preferred food relative to better defended plants.

The problems of allocation to defenses are further complicated by spatial or temporal variations in herbivore grazing rates. If grazing pressure is constant and predictable then prey should maintain uniform levels of defenses (Harvell 1986). However, grazing pressure is seldom constant and only occasionally predictable in marine communities (Lubchenco and Cubit 1980, Cubit 1984). Changes in grazing activity can be brought about by seasonal or even day-to-day variation in weather or water conditions. Movement of herbivores will also cause both spatial and temporal changes in herbivcre pressure. Ideally, defenses against predation should vary with changes in predation rates. Many terrestrial plants use damage by herbivores as a cue to increase concentrations of herbivore-deterrent compounds within their tissues (see reviews by Harbone 1986 and Havel 1986). This type of strategy should be effective only if initial attacks by predators are good predictors of future attacks (Harvell 1986). Herbivoreinduced chemical defenses have not previously been reported in marine or nonvascular plants.

In this study, I show that Fucus distichus, $(=F$. gardneri), a temperate intertidal brown alga, is capable of using physical damage similar to damage caused by herbivores as a cue to increase its production of defensive compounds. I further demonstrate that this increase makes these plants less susceptible to future attacks and hence decreases tissue loss from herbivores by affecting the foraging behavior of the grazers.

\section{Natural history and study sites}

Fucus distichus ssp. edentatus (de la Pyl.) Pow. is an abundant brown alga on sheltered rocky shores of northwestern North America (Abbott and Hollenberg 1976). It often forms extensive beds in the mid to high intertidal, harboring large numbers of herbivorous gastropods and crustaceans (200-5000 grazers $/ \mathrm{m}^{-2} ; \mathrm{K}$.
Van Alstyne, personal observation). Fucus, like other brown algae, produces large quantities of phenolic compounds (Ragan 1976, Ragan and Glombitza 1986) that effectively deter feeding by several marine herbivores (Geiselman 1980, Geiselman and McConnell 1981, Steinberg 1985). These compounds are primarily polymers of phloroglucinol linked by aryl-aryl, etherether, or aryl-ether bonds (Ragan and Glombitza 1986). They bind to both plant and animal proteins, reducing the nutritive value of the plant as well as inactivating herbivore digestive enzymes (Swain 1979). Interspecific differences in phenolic levels in brown algae are negatively correlated with gastropod (Steinberg 1985) and sea urchin (Anderson and Velimirov 1982) food preferences. Both $F$. distichus and $F$. spiralis are lowpreference foods for Littorina sitkana, the herbivorous gastropod investigated in this study, and Littorina scutulata (Van Alstyne 1988).

All of the work done in this study took place on Tatoosh Island, Washington, USA. Collections of $F$. distichus were made on the main beach of the island. This site is a sheltered beach composed mainly of large cobbles and boulders. $F$. distichus grows in an extensive bed here harboring several herbivorous molluscs. Only the gastropods Littorina sitkana, Littorina scutulata, and Siphonaria thersites, and the isopod Idotea wosnesenskii have been observed to graze on $F$. distichus on Tatoosh Island. L. sitkana was the most abundant herbivore at all sites and appeared to be the major source of damage to F. distichus. L. scutulata was common and did some damage to $F$. distichus, whereas $S$. thersites and $I$. wosnesenskii were rare and probably had little impact on the algae. Herbivore densities on the main beach were generally low (Table 1), and many plants showed no sign of herbivore-produced damage. The second study site, Pole Island Draw, was used primarily for transplant experiments. The draw is sheltered from most wave action. The substrate here is mostly bedrock with a few large boulders. Densities of all herbivores were much higher in Pole Island Draw than at the main beach site. All of the $F$. distichus here were grazed, many back to the midrib.

\section{Methods}

\section{Comparisons of phenolic compounds in grazed and ungrazed plants}

Phenolic concentrations were measured in naturally grazed and ungrazed Fucus distichus collected from the main beach on Tatoosh Island in May 1985. Twenty grazed plants were collected from areas where herbivore densities were relatively high. Grazed algae were considered to be those in which at least $10 \%$ of the plant's surface area had been removed by herbivores. Because wave action in this area is low, physical damage due to abrasion was unlikely to be the cause of tissue loss in these plants. Sixty ungrazed plants were collected from areas on the beach where few herbivores 
were present. Only plants that showed no signs of herbivore-produced damage were used for these assays. All the plants used in this study were young, nonreproductive, and ranged from 10 to $15 \mathrm{~cm}$ long. Because $F$. distichus recruits throughout the year (Thom 1983), similar-sized plants are likely to be about the same age.

Phenolic compounds from $F$. distichus were extracted as soon as possible after collecting the plants, usually within $24-48 \mathrm{~h}$. One $0.25-0.50 \mathrm{~g}$ piece of each algal midrib was weighed and placed in $15 \mathrm{~mL}$ of $70 \%$ methanol. Each piece was ground in methanol for 2-4 min using a Virtis " 45 " homogenizer, then filtered through a Whatmann GF/A Glass Microfibre filter. The filtrate was stored at $-10^{\circ} \mathrm{C}$ prior to analysis for phenolic concentrations. Another similar-sized piece of midrib tissue from each plant was weighed and dried for $48 \mathrm{~h}$ at $60^{\circ}$ to obtain a dry mass : wet mass ratio.

Phenolic compounds were quantified using a FolinDenis analysis for total phenols according to Swain and Goldstein (1964). This assay measures amounts of hydroxylated aromatic groups, but does not distinguish between different phenolic compounds. The presence of phloroglucinol polymers was verified using proton nuclear magnetic resonance spectroscopy (K. Van Alstyne and V. J. Paul, personal observation) and Lindt's Reagent (Ragan and Craigie 1978), a vanillin stain specific to phloroglucinol derivatives. A standard curve for the Folin-Denis analyses was derived using phloroglucinol dihydrate. Phenolic concentrations in grazed and uninjured algae were compared using a MannWhitney $U$ test (Sokal and Rohlf 1981).

\section{Clipping experiments}

In order to assess the changes in defensive chemistry that occur when $F$. distichus is injured, I performed a series of experiments in which previously uninjured $F$. distichus were wounded by clipping away $\approx 10 \%$ of the plant's vegetative surface area. Damage to experimental plants was done in a way that mimicked injury by herbivores; tissue was removed from the wings of nonreproductive algae, avoiding injury to the midrib and apices. Plants damaged in this way survive to grow and reproduce and show no obvious signs of stress. Five to 10 clipped and 12 to 27 control plants were left in the field for $2 \mathrm{wk}$. They were then collected, and phenolic levels were analyzed in a single piece of the remaining midrib tissue at the site of injury in the clipped plants and in the midribs of the control plants using the methods described above. These experiments were repeated four times between May 1985 and May 1986. All of the clipping experiments took place on the main beach of Tatoosh Island.

In two of these trials, phenolic concentrations were measured at two or three locations (depending upon the size of the plant) along the midrib of the clipped plants to determine whether the change in defensive compounds was a general response throughout the entire thallus or only a localized response to the injury.

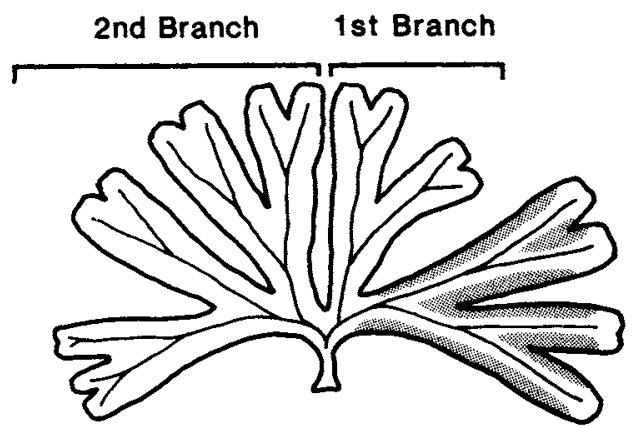

FIG. 1. Design of clipping experiment for looking at within-plant variation in defenses. The shaded area denotes tissue removed by clipping. Phenolic levels were later measured at one and two branches from the clipped branch.

The plants were clipped as described above; however, phenolic concentrations were measured in midrib tissue at the site of injury and in midrib tissue one and two branches away from the injury (Fig.1) in the clipped plants.

\section{Transplant experiments}

A second series of experiments was done to assess the effects of changes in algal defensive chemistry on the foraging behavior of the herbivorous gastropod Littorina sitkana, the primary consumer of $F$. distichus (K. Van Alstyne, personal observation). In these experiments, clipped and uninjured $F$. distichus were transplanted from the beach, an area where grazer densities were low, to Pole Island Draw, an area with high littorine densities.

Holes $\approx 5 \mathrm{~cm}$ in diameter and $3 \mathrm{~cm}$ deep were chiseled into the rock substrate and then cleared of debris and dust. Fast-drying marine cement was poured into the depressions in the rock (Fig. 2). As the cement began to set, one end of a McMahon 1/A stainless steel fishing swivel with a $2.5-\mathrm{cm}$ steel nail through one end was pushed into the drying cement. Swivels were set up in three arrays of 20 pairs. F. distichus was transplanted by first pulling the plants, along with their holdfasts, from the substrate. If this is done carefully, the entire holdfast can be removed without causing any visible damage to the alga. Part of the rock substrate often came off with the plant. A $1-1.5 \mathrm{~cm}$ piece of surgical tubing ( $3 \mathrm{~mm} \mathrm{[1/8-in.]} \mathrm{inside} \mathrm{diameter,} 8 \mathrm{~mm}$ [ $5 / 16$-in.] outside diameter) was slit lengthwise and wrapped around the stipe of the alga, immediately above the holdfast (Fig. 3). The tubing formed a skirt around the stipe and protected it from abrasion. A $10 \mathrm{~mm}$ diameter cotter ring (obtainable at boating supply stores) was placed inside a number 3 aluminum bird band (Gey Band and Tag Company, Norristown, PA) that was tightened around the stipe to hold the surgical tubing in place. The ring was then attached to the end of the stainless steel swivel that had been imbedded at the transplant site. $F$. distichus transplanted using this procedure had an average loss rate of $0.27 \% / \mathrm{d}$ (3 out 


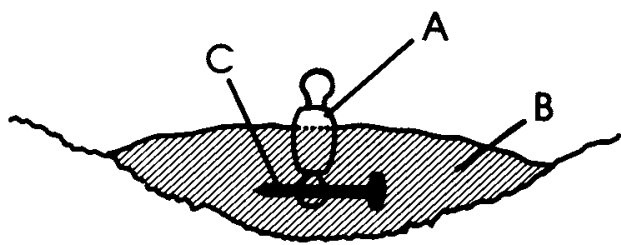

Fig. 2. Stainless steel fishing swivel (A) cemented on the rock substrate. One end of the fishing swivel was embedded in the cement (B) and anchored with $2.5-\mathrm{cm}$ steel nail (C).

of 130 transplanted plants were lost). Because the plants were moved during a low tide they did not receive longer than normal emersion. As a result, none of the algae appeared stressed in any way. Transplanted $F$. distichus continued to increase in length and several plants became reproductive after being moved. None of the algae developed red patches on the thallus or softened tissue that are characteristic of stressed Fucus (Schonbeck and Norton 1980). Phenolic concentrations were measured in 10 uninjured transplanted and 10 uninjured control plants to insure that there was no change in amounts of these compounds caused by transplanting the algae.

In the first set of experiments, which took place in May 1986, plants were clipped and then were immediately transplanted in 19 pairs $(2-3 \mathrm{~cm}$ apart) with undamaged control plants. Paired comparisons were used because of the high spatial heterogeneity in herbivore density. By transplanting the plants immediately after clipping there is insufficient time for the production of additional phenolic compounds; therefore the levels of defensive compounds in the control and clipped algae should be the same. A second set of nine plants from the main beach was clipped and then transplanted $2 \mathrm{wk}$ after injury, a procedure that allows the clipped plants time to increase their concentrations of defensive compounds prior to being offered to the herbivores. On the day following transplanting, the number of $L$. sitkana foraging on each plant was counted at the next two low tides. The number of snails grazing on $F$. distichus were later normalized by plant surface area and compared using a Wilcoxon Signed Ranks test for paired comparisons (Sokal and Rohlf 1981).

Another set of 20 clipped $F$. distichus and 20 control plants had been transplanted in September 1985 in order to compare the relative amounts of tissue loss by clipped and uninjured plants over a 2-wk period. After 2 wk plants were removed and photocopied onto acetate transparencies from which surface area measurements were made using a LI-COR 3000 Surface Area meter. The portions of the plant that had been removed by grazers was drawn in on the acetate using a black pen and the area of the "ungrazed" plant was measured. The surface area removed by grazers was calculated as the final value minus the initial value and compared using a sign test. One week after these plants were transplanted I counted the number of $L$. sitkana grazing on each plant at $1-2 \mathrm{~h}$ intervals throughout the day. $L$. sitkana counts were normalized by plant size and compared using a Wilcoxon Signed Ranks test for paired comparisons.

\section{RESULTS \\ Differences in naturally grazed and ungrazed algae}

In May 1985, Fucus distichus that were grazed by herbivores had significantly $(P<.001)$ higher levels of phenolic compounds than did ungrazed plants. Mean phenolic concentrations (as percent of dry mass \pm 1 SE) in ungrazed plants were $9.64 \pm 0.27 \%$ whereas those in grazed plants were $12.34 \pm 0.54 \%$. These values are significantly different $(P \leq .0001)$ using a Mann-Whitney $U$ test (Sokal and Rohlf 1981). The observed differences in phenolic levels might reflect between-site local selection for better defended plants in areas in which grazing pressures are higher, between-site differences in phenolics for reasons unrelated to herbivore densities, or the presence of herbivore-induced polyphenolic production.

\section{Induction experiments}

When $F$. distichus was damaged by clipping, there was a significant difference in phenolic concentrations in control and clipped plants 2 wk later during the May 1985, June 1985, and September 1985 experiments (Table 2). In these trials, the clipped plants had $\approx 20 \%$ higher concentrations of defensive compounds. However, in the fourth trial there was only an $8 \%$ difference, which was not statistically significant. Analysis of the data from these four experiments using a two-way ANOVA shows that there are significant differences due to both date and clipping (Table 3), with no significant interaction effects between the two factors. When phenolic concentrations were measured in May and June

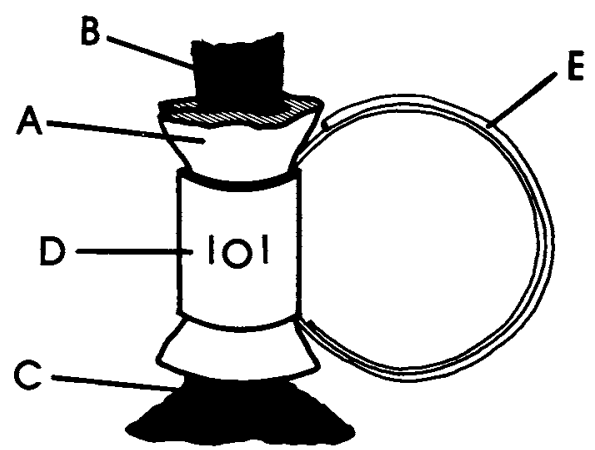

FIG. 3. Apparatus used to transplant Fucus distichus between sites. A small piece of rubber surgical tubing (A) was wrapped around the stipe of the attached plant (B) immediately above the holdfast $(C)$ and secured with an aluminum bird band (D). A cotter ring (E) ran under the bird band and was attached to the free end of the fishing swivel shown in Fig. 2. 
TABLE 2. Phenolic concentrations ( $\bar{X} \pm 1$ SE) of $n$ clipped and uninjured Fucus distichus. Measurements from clipped plants were from the midrib at the site of injury. Measurements from control plants were also made from midrib tissue.

\begin{tabular}{cccc}
\hline & \multicolumn{3}{c}{ Phenolic concentrations (\% dry mass) $\dagger$} \\
\cline { 2 - 4 } Date & Clipped plants & Uninjured plants & $\begin{array}{c}\% \text { in- } \\
\text { crease }\end{array}$ \\
\hline May 1985 & $\begin{array}{c}9.84 \pm 0.49 \\
(n=5)\end{array}$ & $\begin{array}{c}7.89 \pm 0.44 \dagger \\
(n=12)\end{array}$ & 25 \\
July 1985 & $11.93 \pm 0.57$ & $\begin{array}{c}10.15 \pm 0.32 * * \\
(n=27)\end{array}$ & 18 \\
Sept 1985 & $\begin{array}{c}(n=8) \\
\text { May 1986 }\end{array}$ & $\begin{array}{c}9.05 \pm 0.37 \dagger \\
(n=11)\end{array}$ & 20 \\
& $9.38 \pm 0.41$ & $\begin{array}{c}8.65 \pm 0.32 \\
(n=10)\end{array}$ & 8 \\
& $(n=17)$ & \\
\hline
\end{tabular}

$\dagger P<.025 ;{ }^{* *} P<.01 ;$ Mann-Whitney $U$ test comparing clipped vs. unclipped plants.

1986 at different locations within the clipped plants there was no significant difference within individual plants (Table 4).

\section{Responses by herbivores}

The results of the Folin-Denis analysis for total phenolics in plants that were and were not transplanted show that there was no significant difference $(P=.473$ using a Mann-Whitney $U$ test) between phenolic levels of clipped control $(\bar{X} \pm 1 \mathrm{SE}: 6.82 \pm 0.63 \%)$ and transplanted plants $(\bar{X} \pm 1 \mathrm{SE}: 7.19 \pm 0.78 \%$ ). Thus, transplanting algae does not appear to stress the plants in ways that would affect concentrations of these defensive compounds.

The transplant experiments from May 1986 demonstrate that initially, clipped algae are preferred over uninjured control plants (Table 5). Snail densities were $65 \%$ higher on the clipped plants a day after the plants were clipped and transplanted. However, the snails switched their preference from clipped plants to uninjured plants over the 2 -wk period. When plants were transplanted $2 \mathrm{wk}$ after being clipped there were over twice as many snails feeding on undamaged plants. This switch is well-correlated with the increase in defensive compound concentrations of the clipped plants after $2 \mathrm{wk}$. Tissue losses to herbivores were also less in the clipped algae, which lost about half as much photosynthetic surface area to grazers as did the undamaged control plants (Table 6).

Observations of snails feeding throughout the day 1
Table 4. Phenolic concentrations $(\bar{X} \pm 1 \mathrm{SE})$ within $n$ clipped plants. Measurements were made 2 wk following clipping. Concentrations at the site of injury and one and two branches away are not significantly different $(P>.05$ using a oneway ANOVA on arcsin $\sqrt{p}$ transformed data).

\begin{tabular}{lcc}
\hline & \multicolumn{2}{c}{$\begin{array}{c}\text { Phenolic concentrations } \\
\text { (\% dry mass) }\end{array}$} \\
\cline { 2 - 3 } Location within plant* & May 1985 & July 1985 \\
\hline Site of injury & $9.84 \pm 0.49$ & $11.93 \pm 0.57$ \\
& $(n=5)$ & $(n=8)$ \\
One branch away & $10.05 \pm 0.87$ & $11.19 \pm 0.63$ \\
from injury & $(n=5)$ & $(n=8)$ \\
Two branches away & $8.50 \pm 0.98$ & $11.08 \pm 0.95$ \\
from injury & $(n=3)$ & $(n=2)$ \\
\hline
\end{tabular}

* See Fig. 1 for depiction of these locations.

wk after the algae were transplanted showed that Littorina sitkana encountered clipped and uninjured algae at approximately the same rate but moved off the plants at different rates (Fig. 4). L. sitkana were attached to the rock substrate while the tide was in but began to forage soon after it receded. Initially, the snail densities on the clipped and undamaged plants were the same, however at low tide the densities of $L$. sitkana were significantly less on the clipped plants. As the snails moved off the plants onto the rock substrate prior to the incoming tide, the densities on clipped and undamaged plants no longer showed a significant difference.

\section{DISCUSSION}

In these experiments, I have demonstrated that marine algae can use physical damage, such as that which might be produced by herbivory, as a cue for the production of additional defensive chemicals that can reduce future losses to grazers. This causes both spatial and temporal changes in polyphenolic concentrations within and between individual plants. This type of variation in defense composition may cause both intraand interspecific food preferences to change over small distances or time intervals. If predation pressure is severe enough to affect prey survivorship, differences in preferences could have an effect on community organization.

Intraspecific variations in defenses have been reported from many aquatic organisms. Chemical defenses in algae vary spatially, ranging in scale from between-population to within-plant differences (Gaines 1985, Paul and Van Alstyne 1987). This variation oc-

TABLE 3. Two-way analysis of variance for Fucus distichus clipping experiments.

\begin{tabular}{lrrrrr}
\hline \hline Source & df & ss & MS & \multicolumn{1}{c}{$F$} & $P$ \\
\hline Date & 3 & 68.539 & 22.846 & 9.809 & $<.001$ \\
Clipping & 1 & 41.634 & 41.634 & 17.880 & $<.001$ \\
Time $\times$ clipping & 3 & 14.218 & 4.739 & 2.035 & NS \\
Error & 94 & 218.906 & 2.329 & & \\
Total & 101 & 343.297 & & & \\
\hline
\end{tabular}




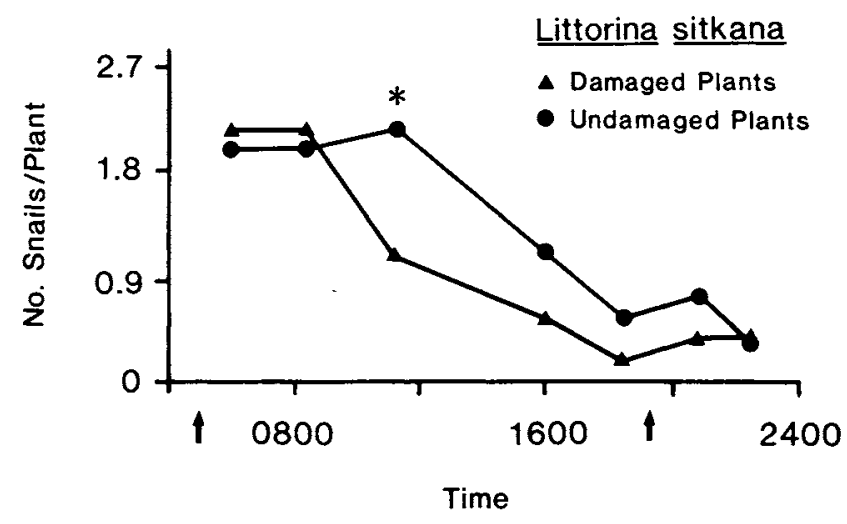

Fig. 4. Number of Littorina sitkana on clipped and uninjured algae throughout a tidal cycle. Herbivore numbers were normalized by plant surface area. Arrows mark the time of the high tides. Significantly different $(P<.05$ using a Wilcoxon Signed Ranks test) densities are marked with an asterisk.

curs both in the compounds present and in their amounts. Daily (Paul and Van Alstyne 1987) and seasonal (Ragan and Jensen 1978, Geiselman 1980) variation in algal chemical defenses have also been reported. Few cases of variation in secondary metabolite production in marine animals have yet been documented, although predator-induced morphological defenses have been reported in bryozoa (Harvell 1984, 1985, 1986), barnacles (Lively 1986a, b), rotifers (Gilbert and Stemberger 1984, Stemberger and Gilbert 1984), and a tropical brown alga (Lewis et al. 1987).

Interpopulation variation in defensive compound concentrations and predator-induced chemical defenses are also common in terrestrial plants (Denno and McClure 1983, Harbone 1986, Havel 1986). Havel (1986), in a recent review of the literature on consumerinduced defenses, reports 43 examples of herbivoreinduced defenses in terrestrial plants. In 33 of these examples, the compounds that increase subsequent to herbivore attacks are known. Thirteen of these $33 \mathrm{com}$ pounds are phenolic metabolites. This high representation of phenolics among induced compounds is prob-

TABLE 5. Numbers of Littorina sitkana $(\bar{X} \pm 1 \mathrm{SE})$ foraging on $n$ Fucus distichus that had been transplanted to a site where herbivores were abundant, either immediately or 15 $\mathrm{d}$ after being clipped.

\begin{tabular}{ccc}
\hline \hline \multirow{2}{*}{$\begin{array}{c}\text { Time of transplant } \\
\text { (days following } \\
\text { clipping) }\end{array}$} & \multicolumn{2}{c}{ Number of foraging snails per plant $\ddagger$} \\
\cline { 2 - 3 } & Clipped plants & Uninjured plants \\
\hline 1 & $1.30 \pm 0.19$ & $0.80 \pm 0.16^{* * *}$ \\
& $(n=19)$ & $(n=18)$ \\
15 & $2.71 \pm 0.05$ & $5.72 \pm 0.09 \dagger$ \\
& $(n=9)$ & $(n=9)$ \\
\hline
\end{tabular}

$\dagger P<.025 ; * * * P<.001 ;$ Wilcoxon Signed Ranks tests for paired comparisons of clipped vs. uninjured plants within each transplant time.

$¥$ Snails were counted on each plant $1 \mathrm{~d}$ after the plants were transplanted. These values were normalized by plant surface area. ably a reflection of the ease with which total phenolic levels can be measured. If simple assays were available for measuring other types of secondary compounds, the proportion of species in which herbivore-induced increases in phenolic compounds have been reported might be much lower.

Damage-induced changes in plant chemistry appeared to account for most of the interpopulation variation that I observed. The spatial variation in phenolic concentrations that I observed between the grazed and ungrazed populations of $F$. distichus could have resulted from either (1) the presence of induced defenses, (2) localized selection for higher concentrations of defensive compounds in areas of high grazing intensity, or (3) between-site differences in phenolic concentrations that were unrelated to herbivore density. The results of the clipping experiments indicate that the first hypothesis is the most probable since the increases in phenolic concentrations due to clipping the plants corresponded well with the increased levels seen in the populations of grazed algae. This does not entirely rule out the possibility that localized selection or differences caused by other factors may also operate in causing between-site variation within these plants.

Increases in polyphenolic concentrations brought

TABLE 6. Tissue surface area (SA) loss to herbivores $(\bar{X} \pm$ $1 \mathrm{SE}$ ) in $n$ clipped and injured Fucus distichus. Plants were transplanted to an area of high herbivore density in pairs of one clipped and one uninjured plant immediately after damage to clipped plants. Surface areas were measured 2 wk after transplanting.

\begin{tabular}{ccc}
\hline \multicolumn{1}{c}{ Measure } & Clipped & Uninjured \\
\hline $\begin{array}{ccc}\text { Absolute SA removed } \\
\left(\mathrm{cm}^{2} / \mathrm{d}\right)\end{array}$ & $0.42 \pm 0.08$ & $0.76 \pm 0.14^{*}$ \\
Proportion SA removed & $0.58 \pm 0.10$ & $0.97 \pm 0.18^{*}$ \\
$(\% / \mathrm{d})$ & $(n=18)$ & $(n=18)$ \\
\hline
\end{tabular}

* $P<.05$; Wilcoxon Signed Ranks tests for paired comparisons. 
about by damage to $F$. distichus were $\approx 20 \%$ above background phenolic levels, which fluctuated seasonally. Seasonal variation in polyphenol levels has been well documented in Fucus vesiculosus (Ragan and Jensen 1978, Geiselman 1980). Geiselman (1980) suggests that polyphenolic levels are highest at the time of peak grazing intensity. Although temporal changes in polyphenolic compounds have not been documented in Fucus distichus on the northeast Pacific coast, it is likely that regular seasonal variation also occurs. During the year in which the clipping experiments were done there was considerable temporal variability in phenolic concentrations between experiments. These levels were highest in midsummer (July) and lower in the spring (May) and autumn (September). Both Littorina sitkana and $L$. scutulata are inactive during periods of heavy rainfall but more active in foggy weather $(\mathrm{K}$. Van Alstyne, personal observation). The Washington coast receives most of its rainfall during the winter and very little in summer months, with intermediate amounts occurring in the spring and fall (Anonymous 1983). Coastal fogs occur primarily in the summer (Dayton 1971, Thomson 1981, Paine 1984). Thus, littorine activity should be highest in summer. The polyphenolic levels that were measured in this study were higher in midsummer than in the spring or fall, which corresponds with the expected levels of grazer activity.

Qualitative changes in polyphenolic compounds may also occur when defenses are induced. Because concentrations of compounds were quantified using a general assay for polyphenolics, it is not known specifically which metabolites were increasing when the plant was wounded. Ragan and Craigie (1978) have separated at least six phloroglucinol-containing compounds from Fucus vesiculosus. Phloroglucinol polymers are more polar than most algal secondary metabolites. Thus, they tend to be more difficult to isolate and identify than other defensive compounds. In general, ecologists have avoided working with individual phenolic compounds because of the difficulties involved in isolating them and because of the availability of general assays such as the Folin-Denis analysis. Hence, little is known about the variation and action of individual metabolites. In $F$. distichus, the $20 \%$ increase in defensive compounds that occurs when the plant is clipped could result from a $20 \%$ increase in all phenolic compounds, a greater increase in one or more individual compounds, or the de novo synthesis of new metabolites. Further work is needed to identify the specific activities of individual metabolites and to quantify temporal changes in their abundances.

The benefits to be gained by producing inducible defenses may not be limited to herbivore deterrence. Fucoid algae release polyphenolic compounds in to seawater (Craigie and McLachlan 1964, Sieburth 1969, Sieburth and Jensen 1969, Carlson and Carlson 1984). These types of compounds have been shown to inhibit growth of bacteria and epiphytes (Conover and Sie- burth 1964, McLachlan and Craigie 1966). Thus, damaged plants with higher levels of these compounds may be less susceptible to invasion by pathogens and other algae than are wounded plants that do not increase concentrations of phenolic compounds. Phenolic compounds may also aid in wound healing through their protein-binding properties. However, if the sole reason for increasing the use of these compounds were to heal wounds, phenolic levels would not be expected to increase across the entire thallus of the injured plant.

The induction of chemical-defense production by marine plants may also affect foraging strategies of herbivores and the risks associated with foraging. Because the induction of antiherbivore compounds causes plant nutritional quality to vary in time and space, herbivores should not feed continuously on a single plant but should move in search of better food as the quality of the alga they are feeding on declines. Snails moving to a new area may be susceptible to higher levels of predation, desiccation, or wave exposure (Behrens 1972). L. sitkana that do not find crevices in which to hide during the high tide can be carried up to $2 \mathrm{~m}$ away by tidal water movement (K. Van Alstyne, personal observation). Because these snails often occupy habitats that are near sandy beaches, they are in danger of becoming buried in sand if they are washed off rock substrates. Thus, induced defenses in algae may affect herbivores not only by decreasing the quality of the food but also by increasing the risks associated with foraging.

How does a signal to induce chemical defense production get transported from a wound to distant tissues in a "nonvascular" plant? Marine algae either lack vascular systems or, like Fucus, have a series of tracheal cells that may form a primitive transport system (Moss 1983, Diouris and Floc'h 1984). In addition, waterborne cues, similar to the air-borne cues found to induce defenses in terrestrial plants (Baldwin and Schultz 1983), could operate in inducing defenses in algae. If cues cannot be sent to different parts of the plant internally, then they might be transported externally, either in air or water. If this mechanism is operating in Fucus, then it should produce interplant induction of chemical defenses. Because the plants in the clipping experiments were only a few centimetres apart, defenses should have been induced in control plants if this mechanism were operating. Therefore, it is unlikely that air-borne or water-borne cues induce increased phenolic production within individual plants.

Consumer-induced defenses are a common phenomenon in marine, freshwater, and terrestrial predatorprey systems (Havel 1986). Little is known about the importance of induced defenses in structuring populations and communities. However, they may affect differential survival and reproduction of the prey (Harvell 1986), decrease predator fitness, and cause variation in preferences by generalist consumers for different plant species. Shifts in preferences could 
conceivably cause local extinctions of more poorly defended species, thereby driving changes in the diversity and structure of the community. Clearly, much more needs to be known about the mechanisms underlying defense induction and the effects of induced defenses on the dynamics of predator-prey interactions.

\section{ACKNOWLEDGMENTS}

I am very grateful to $R$. T. Paine for his advice, assistance, and encouragement throughout this project. I thank D. Rhoades and L. Erckmann for helping me with the FolinDenis analyses. D. Harvell, S. Nelson, G. Orions, R. Paine, D. Rhoades, W. Sousa, P. Steinberg, R. Strathmann, and R. Waaland and an anonymous reviewer's comments greatly improved various versions of this manuscript. I also thank the Makah Tribal Council for allowing me access to Tatoosh Island and the folks at Big Salmon and Eagle Air for getting me on and off the island. This research was supported by NSF grant OCE 84-15707 to R. T. Paine, Whitehall Foundation grant \#83548 to D. F. Rhoades, and by a Sigma Xi Grantin-Aid of Research, a grant from the Lerner Grey Fund for Marine Research, and an NSF Predoctoral Fellowship to the author.

\section{Literature Cited}

Abbott, I. A., and G. H. Hollenberg. 1976. Marine algae of California. Stanford University Press, Stanford, California, USA.

Anderson, R. J., and B. Velimirov. 1982. An experimental investigation of the palatability of kelp bed algae to the sea urchin Parechinus angulosus Leske. (Pubblicazioni della Stazione Zoologica di Napoli I) 3:357-373.

Anonymous. 1983. Climate normals for the U.S. (Base: 195180). National Oceanic and Atmospheric Administration, Washington, D.C., USA.

Baldwin, I. T., and J. C. Schultz. 1983. Rapid changes in tree leaf chemistry induced by damage: evidence for communication between plants. Science 221:227-229.

Behrens, S. 1972. The role of wave impact and desiccation on the distribution of Littorina sitkana Philippi, 1845 . Veliger 15:129-132.

Carlson, D. J., and M. L. Carlson. 1984. Reassessment of exudation by fucoid macroalgae. Limnology and Oceanography 29:1077-1087.

Coley, P. D. 1986. Costs and benefits of defense by tannins in a neotropical tree. Oecologia (Berlin) 70:238-241.

Coley, P. D., J. P. Bryant, and F. S. Chapin III. 1985. Resource availability and plant antiherbivore defense. Science 230:895-899.

Conover, J. T., and J. McN. Sieburth. 1964. Effect of Sargassum distribution on its epibiota and antibacterial activity. Botanica Marina 6:147-157.

Craigie, J. S., and J. McLachlan. 1964. Excretion of coloured ultraviolet absorbing substances in marine algae. Canadian Journal of Botany 42:23-33.

Cubit, J. D. 1984. Herbivory and the seasonal abundance of algae on a high intertidal rocky shore. Ecology 65:19041917.

Dayton, P. K. 1971. Competition, disturbance and community organization: the provision and subsequent utilization of space in a rocky intertidal community. Ecological Monographs 41:35l-389.

Denno, R. F., and M. S. McClure. 1983. Variable plants and herbivores in natural and managed systems. Academic Press, New York, New York, USA.

Diouris, M., and J.-Y. Floc'h. 1984. Long-distance transport of ${ }^{14} \mathrm{C}$-labelled assimilates in the Fucales: directionality, pathway and velocity. Marine Biology 78:199-204.
Faulkner, D. J. 1984. Marine natural products: metabolites of marine algae and herbivorous marine mollusks. Natural Products Reports 1:251-280.

Gaines, S. D. 1985. Herbivory and between-habitat diversity: the differential effectiveness of plant defenses in a marine plant. Ecology 66:473-485.

Geiselman, J. A. 1980. Ecology of chemical defenses of algae against the herbivorous snail, Littorina littorea, in the New England rocky intertidal community. Dissertation. Woods Hole Oceanographic Institution/Massachusetts Institute of Technology, Woods Hole, Massachusetts, USA.

Geiselman, J. A., and O. J. McConnell. 1981. Polyphenols in brown algae Fucus vesiculosus and Ascophyllum nodosum: chemical defenses against the marine herbivorous snail, Littorina littorea. Journal of Chemical Ecology 7:1115-1133.

Gilbert, J. J., and R. S. Stemberger. 1984. Asplanchna-induced polymorphism in the rotifer Keratella slacki. Limnology and Oceanography 29:1309-1316.

Harbone, J. B. 1986. Recent advances in chemical ecology. Natural Products Reports 1986:323-344.

Harvell, C. D. 1984. Predator-induced defense in a marine bryozoan. Science 224:1357-1359.

- 1985. Partial predation, inducible defenses, and the population biology of a marine bryozoan (Membranipora membranacea). Dissertation. University of Washington, Seattle, Washington, USA.

- 1986. The ecology and evolution of inducible defenses in a marine bryozoan: cues, costs, and consequences. American Naturalist 128:810-823.

Havel, J. 1986. Predator-induced defenses: a review. Pages 263-278 in W. C. Kerfoot and A. Sih, editors. Predation: direct and indirect effects on aquatic communities. University Press of New England, Hanover, New Hampshire, USA.

Hawkins, S. J., and R. G. Hartnoll. 1985. Grazing of intertidal algae by marine invertebrates. Oceanography and Marine Biology: Annual Review 21:195-282.

Hay, M. E. 1981. The functional morphology of turf-forming seaweeds: persistence in stressful marine habitats. Ecology 62:739-750.

Lewis, S. M., J. N. Norris, and R. B. Searles. 1987. The regulation of morphological plasticity in tropical reef algae by herbivory. Ecology 68:636-641.

Littler, M. M., and D. Littler. 1980. The evolution of thallus form and survival strategies in benthic marine macroalgae: field and laboratory test of a functional form model. American Naturalist 116:25-44.

Lively, C. M. 1986a. Competition, comparative life histories, and maintenance of shell dimorphism in a barnacle. Ecology 67:858-864.

-_. 1986b. Predator-induced shell dimorphism in the acorn barnacle Chthamalus anisopoma. Evolution 40:232242.

Lubchenco, J. 1978. Plant species diversity in a marine rocky intertidal community: importance of herbivore food preference and algal competitive abilities. American Naturalist 112:23-39.

Lubchenco, J., and J. Cubit. 1980. Heteromorphic life histories of certain marine algae as adaptations to variations in herbivory. Ecology 61:676-687.

Lubchenco, J., and S. D. Gaines. 1981. A unified approach to marine plant-herbivore interactions. I. Populations and communities. Annual Review of Ecology and Systematics 12:405-437.

McConnell, O. J., P. A. Hughes, N. M. Targett, and J. Daley. 1982. Effects of secondary metabolites from marine algae on feeding by the sea urchin, Lytechinus variegatus. Journal of Chemical Ecology 8:1437-1453.

McKey, D. 1979. The distribution of secondary compounds within plants. Pages 56-134 in G. A. Rosenthal and D. H. 
Janzen, editors. Herbivores: their interaction with secondary plant metabolites. Academic Press, New York, New York, USA.

McLachlan, J., and J. S. Craigie. 1966. Antialgal activity of some simple phenols. Journal of Phycology 2:133-135.

Moss, B. 1983. Sieve elements in the Fucales. New Phytologist 93:433-437.

Norris, J. N., and W. Fenical. 1982. Chemical defense in tropical marine algae. Pages $417-431$ in K. Rutzler and I. G. Macintyre, editors. The Atlantic Barrier Reef ecosystem at Carrie Bow Cay, Belize I: structure and communities. Smithsonian Contributions to the Marine Sciences 12.

Paine, R. T. 1984. Ecological determination in the competition for space. Ecology 65:1339-1348.

Paul, V. J., and M. E. Hay. 1986. Seaweed susceptibility to herbivory: chemical and morphological correlates. Marine Ecology Progress Series 33:255-264.

Paul, V. J., and K. L. Van Alstyne. 1987. Chemical defense and chemical variation in the genus Halimeda. Coral Reefs, in press.

Ragan, M. A. 1976. Physodes and phenolic compounds of brown algae. Composition and significance of physodes in vivo. Botanica Marina 19:145-154.

Ragan, M. A., and J. S. Craigie. 1978. Phenolic compounds in brown and red algae. Pages 157-179 in J. A. Hellebust and J. S. Craigie, editors. Handbook of phycological methods. Volume II. Cambridge University Press, Cambridge, England.

Ragan, M. A., and K. Glombitza. 1986. Phlorotannins, brown algal polyphenols. Pages $129-241$ in F. E. Round and D. J. Chapman, editors. Progress in phycological research. Volume 4. Biopress, Bristol, England.

Ragan, M. A., and A. Jensen. 1978. Quantitative studies on brown algal phenols. II. Seasonal variation in polyphenol content of Ascophyllum nodosum (L.)LeJol. and Fucus vesiculosus (L.). Journal of Experimental Marine Biology and Ecology 34:245-258.

Schonbeck, M. W., and T. A. Norton. 1980. The effects on intertidal fucoids of exposure to air under various conditions. Botanica Marina 23:141-147.

Sieburth, J. M. 1969. Studies on algal substances in the sea. III. The production of extracellular organic matter by littoral marine algae. Journal of Experimental Marine Biology and Ecology 3:290-309.
Sieburth, J. M., and A. Jensen. 1969. Studies on algae substances in the sea. II. The formation of Gelbstoff (humic material) by phaeophyte exudates. Journal of Experimental Marine Biology and Ecology 3:275-289.

Sokal, R. R., and F. J. Rohlf. 1981. Biometry. W. H. Freeman, New York, New York, USA.

Steinberg, P. D. 1984. Algal chemical defenses against herbivores: allocation of phenolic compounds in the kelp Alaria marginata. Science 223:405-407.

- 1985. Feeding preferences of Tegula funebralis and chemical defenses of marine brown algae. Ecological Monographs 55:333-349.

Stemberger, R. S., and J. J. Gilbert. 1984. Spine development in the rotifer Keratella cochlearis: induction by the cyclopoid copepods and Asplanchna. Freshwater Biology 14:639-647.

Steneck, R. S., and L. Watling. 1982. Feeding capabilities and limitations of herbivorous molluses: a functional group approach. Marine Biology 68:299-319.

Swain, T. 1979. Secondary compounds as protective agents. Annual Review of Plant Physiology 28:429-501.

Swain, T. S., and J. L. Goldstein. 1964. The quantitative analysis of phenolic compounds. Pages 131-146 in J. B. Pridham, editor. Methods in polyphenol chemistry. Macmillan, New York, New York, USA.

Thom, R. M. 1983. Spatial and temporal patterns of Fucus distichus ssp. edentatus (de la Pyl.) Pow. (Phaeophyceae: Fucales). Botanica Marina 26:471-486.

Thomson, R. E. 1981. Oceanography of the British Columbia Coast. Canadian Special Publication of Fisheries and Aquatic Sciences 56.

Vadas, R. L. 1977. Preferential feeding: an optimization strategy in sea urchins. Ecological Monographs 47:337-371.

Van Alstyne, K. L. 1988. The ecology and evolution of antiherbivore defenses in fucoid brown algae. Dissertation. University of Washington, Seattle, Washington, USA.

Watson, D. C., and T. A. Norton. 1985a. Dietary preferences of the common periwinkle, Littorina littorea (L.). Journal of Experimental Marine Biology and Ecology 88: $1-19$.

Watson, D. C., and T. A. Norton. 1985b. The physical characteristics of seaweed thalli as deterrents to littorine grazers. Botanica Marina 28:383-387. 